\title{
Research on Training Mode of Compound Foreign Language Talents on the Background of "One Belt And One Road"
}

\author{
Ping Wang \\ College of Foreign Languages, Bohai University, Jinzhou, 121013, China \\ zrmitbo@qq.com
}

Keywords: One Belt And One Road; compound foreign language talents; training mode; training strategies

\begin{abstract}
The cultivation of compound foreign language talents is the objective requirement of "One Belt and One Road" national strategy, aiming at the existed problems of foreign language teaching. The basic features of compound talents are studied, which include high comprehensive quality, good knowledge structure, fast learning transfer and social adaptability; The talents demand on the background of "One Belt and One Road" are analyzed, including application foreign language talents with high comprehensive quality, research foreign language talents with strong innovation and management foreign language talents with broad knowledge; The strategy of cultivation mode foreign languages talents on the background of "One Belt and One Road", including: training objectives from social demand, optimize foreign language talents training curriculum system, construct a practical teaching system of scientific system, to adapt to the development and promotion of mobile learning, strengthen the construction of compound foreign language teachers, reform the traditional teaching methods and teaching means, and actively build the school and enterprise cooperation platform.
\end{abstract}

\section{Introduction}

"One Belt and One Road" is short of "Silk Road Economic Belt" and "maritime Silk Road in twenty-first Century". The "One Belt and One Road" line has been throughout Eurasia, connecting the East Asia Pacific Economic Circle, into the West European Economic circle. Whether it is the development of the economy and improving people's livelihood, or to respond to the crisis and accelerate the adjustment, many countries along the line with the common interests of china. In history, the Silk Road and the maritime silk road is exchange channel among Chinese, Central Asia, Southeast Asia, South Asia, West Asia, East Africa, European Economic and trade and cultural. "One Belt and One Road" is the inheritance and the promotion of the ancient Silk Road, which has been widely accepted. "One Belt and One Road" strategy has an important and profound significance on Chinese opening to realize strategy change: "One Belt and One Road" conforms to the regional structural transformation of the Chinese opening; "One Belt and One Road" conforms to the Chinese factor flow transformation and international industrial transfer; "One Belt and One Road" conforms to the need of structural change of China with other economic cooperation countries; "One Belt and One Road" conforms to the needs of international trade and economic cooperation and its mechanism transformation.

With the promotion of "One Belt and One Road" national strategy, the link among Chinese and neighboring countries is more closely, the political, economic, cultural and religious exchanges are more frequent. In a wide range of international communication, the language is bound to be carried out under different national and cultural background, the huge differences between languages and cultures in different countries, often resulting in barriers to communication. In order to better promote cross-cultural communication, confirm to peace, development, cooperation and win-win the "One Belt and One Road" trend of the times, strengthen the cultivation of foreign language talents is imperative. In order to comply with the "One Belt and One Road", university education should also show some of the international and world level, abandon the previous foreign language teaching profession, knowledge in narrow, outdated teaching content and knowledge structure sole, 
cultivate and adapt to the economic construction, and adapt to social and cultural development of science and technology of the compound applied talents of foreign languages.

\section{Basic Characteristics of Compound Talents}

Compound talents are refers to people through the certain education training mode, with solid basic theory and encyclopedic knowledge, master the basic two or two above theories, knowledge and skills, rich interdisciplinary consciousness and spirit of innovation. The important features of today's society are the intersection of disciplines, knowledge integration and technology integration. This feature determines everyone to improve their overall quality, both to expand knowledge and constantly adjust their mentality, change their thinking, strive to cultivate themselves become talents to meet the needs of social development. Compound talents have the following basic characteristics:

(1) High Comprehensive Quality. The comprehensive quality is a person's knowledge level, moral accomplishment and all kinds of ability and so on. The overall improvement of human comprehensive quality is the general requirement and trend of social development, especially in the era of knowledge economy and society; to improve the comprehensive quality is particularly urgent. The compound talents of physiology, psychology and social cultural quality is high, have rich imagination and creative thinking ability, good at transferring cultural and scientific knowledge, social behavior norms and social practice experience into individual psychological quality. The comprehensive quality of college students is mainly reflected in the aspects of human affairs, logical thinking and innovation.

(2) Good Knowledge Structure. Knowledge structure is the composition and combination of a person's knowledge system. Reasonable knowledge structure is both a depth of expertise, and extensive knowledge and most optimization and most reasonable knowledge system of practical needs in career development. The compound knowledge structure of talents is regard professional knowledge as the center, and r similar with other profession or greater interaction of knowledge as a network connection, form a strong adaptability, and in a large range of knowledge about gallop network. For college students, it is mainly to cultivate scientific thinking mode and improve practical skills to meet the needs of social development in the future.

(3) Fast Learning Transfer. Learning transfer refers to the influence of one kind of learning on another or the knowledge gained from the experience to other activities. Transfer is an important learning ability, which directly affects the process and efficiency of learning; Transfer is an important part of the ability to form, has a role of promotion of improving the ability solve problems. Compound Talents can be a subject to obtain knowledge, skill or attitude, applied to other disciplines or other situations, to create new experiences and achievements to acquired knowledge and skills, to speed up the learning process. Cultivating students' ability to migrate is also an important task for teachers.

(4) Strong Social Adaptation. Adaptive ability is the personality characteristic of the individual and the environment in the process of adaptation. The ability of social adaptation, including the ability to take care of oneself, the ability to work, choose and engage in some kind of occupation, social intercourse ability and moral criterion. The ability of social adaptation is the indirect expression of the ability of a person's comprehensive ability, and it is a manifestation of the integration of society and the acceptance of social ability. Compound talents have solid foundation, wide knowledge, professional ability, reasonable knowledge structure, so they has strong adaptability, they are able to do well in a complex society, to make up the defect of professional talents' application is not strong.

\section{Demand on Compound Foreign Language Talents on the Background of "One Belt And One Road"}

The core "One Belt and One Road" is to hold high the banner of peaceful development, to take the initiative to develop economic partner's relations with countries along, together to build political 
trust, economic integration and cultural inclusive community of interests, the fate of the community and responsibility community. The traditional cultivation mode of talents based language skill is not suited to the objective requirements of "One Belt and One Road". According to the cooperation field of "One Belt and One Road", the society urgent need the compound foreign language talents set "professional knowledge + foreign language skills + culture". Specific requirements are as follows:

(1) High Comprehensive Quality of Applied Foreign Language Talents. Application talents are a type of talents can applied the professional knowledge and skills to social practice, master the basic knowledge and basic skills of social production or social activities. In the construction of "One Belt and One Road", requires a lot of application oriented foreign language talents serving economic and social development. Applied Foreign Language Talents not only have foreign language knowledge and foreign language skills, but also have a high comprehensive quality, with strong analytic and problem-solving skills.

(2) Strong Innovative Ability of the Research Foreign Language Talents. Innovation is the soul of the national progress and the inexhaustible motive force for the prosperity of the country, which is the quality that the modern people should have. "One Belt and One Road" reflects the innovative Chinese global strategy, which also need philosophy and practice of innovation in the process of implementation. It requirements foreign language talents have foreign language knowledge and skills, intercultural background knowledge and communicative competence, and interdisciplinary professional knowledge and innovation ability, to meet the demand of the "One Belt and One Road" continuous innovation in the development process.

(3) Wide Range of Knowledge Management Oriented Foreign Language Talents. Management personnel economic management activities need extensive knowledge and social experience, a profound understanding of human behavior and interpersonal relationships, strong organizational skills and communication skills. "One Belt and One Road" construction need more compound talents not only have a good language foundation, but also grasp business management knowledge. These personnel in complete management functions to improve the competitiveness of enterprises directly use foreign languages for intercultural communication to avoid the information loss caused by translators.

\section{Strategies on Training Mode of Compound Foreign Language Talents on the Background of "One Belt And One Road"}

"Personnel training mode" refers to the guidance of modern education theory and education theory, in accordance with the specific objectives and the training of talents, relatively stable teaching contents and curriculum system, management system and evaluation methods, the implementation process of the sum of talent education. Specifically, it contains four meanings: training objectives and specifications; the whole process of education training objectives and specifications; a set of management and evaluation system to achieve this process; the scientific teaching methods, and means to match it. The cultivation of English talents is not only a single training can only communicate in English, but does not have the ability to analyze and solve problems independently. They are not only to maintain the advantages of foreign language students, but also some excellent professional knowledge. In the training mode of choice, conform to the "One Belt and One Road" actual demand of foreign language talents, out of the traditional foreign language talents cultivation mode of misunderstanding. Specific strategies are as follows:

(1) According to the needs of the community to develop training objectives. The training target is the purpose of education in specific in educational institutions at all levels, is an important basis for the construction of personnel training system for various kinds of schools. It plays an important role on personnel training, and also in guiding, stability, regulation and incentive effects on the development of educational activities. More and more talents welcomed by the society, which is the new requirements of the socialist market economy of English professional education, the demand for talents of twenty-first Century, and need to "One Belt and One Road" development strategy. The specific objectives are: the solid basic skill of English language, broad knowledge, certain language 
knowledge and comprehensive application ability of English; master the basic knowledge of a professional direction and basic skills; to obtain knowledge, use of information, independent thinking and innovation ability; have good learning habits and strong ability of self-study.

(2) Optimizing the course system of foreign language talents training. Curriculum system refers to the same professional but different courses in accordance with the order of categories, is the sum of the teaching content and process. The curriculum categories determine how the students get the knowledge structure. The curriculum system should be professional foreign language skills, language knowledge and related professional knowledge such three aspects of optimization of training talents of foreign languages: English skills including comprehensive training courses and training courses for individual English skills; English profession knowledge including language, literature, culture and other aspects of the curriculum; related professional knowledge is other professional knowledge courses related to English. Through the "compound" with the relevant professional knowledge, ensure the realization of the goal of training compound foreign language talents. At the same time, it should be noted that the curriculum system compound is not only compound of profession courses, but also the combination of professional courses and non professional courses, compulsory courses and elective courses, explicit courses and potential courses.

(3) Constructing the practical teaching system of scientific system. Practical teaching is an important part of higher education, it is an important means to cultivate students' innovative spirit and improve comprehensive quality, and it is the key link to cultivate innovative talents. Constructing the practical teaching system of scientific system is the guarantee to realize the goal of talent training. Practical teaching system should be designed in three aspects: goal, content and safeguard mechanism, to realize the overall reform of the practice of foreign language teaching. Let the students from the classroom, foreign language autonomous learning center, the foreign language training center, the second classroom and social and other channels realize foreign language practice, promote classroom teaching and network practice, theory teaching and practice teaching, cultivation in class and guidance after class, special practice and individual practice, the school practice and the practice of the "five organic combination", effectively promote the reform of the deep development of foreign language teaching. It improves students' language skills and communicative competence through practical teaching.

(4) Adapt to the development of the times to promote mobile learning. Mobile learning is a new learning mode for gain learning resources, which is based on the study of wireless network and mobile communication equipment and come after the digital learning. It is a frontier and hot spot in the field of educational technology. Foreign language learning has the typical characteristics of micro learning, which suitable to use the small time dispersion for learning; mobile provides rich video and audio feature, which can provide authentic language environment for students; The intelligent mobile terminals such as mobile phone and notebook computer has been popular among college students, laid the material foundation for the development of mobile learning. Mobile learning in foreign language teaching, establish the mechanism of student-centered classroom teaching, effectively compensate for the traditional shortcomings. There, students can obtain illustrations whenever and wherever possible static and dynamic combination of resources, which is conducive to stimulate learners' interest in learning English, enhance the independent learning ability, and improve English comprehensive application ability.

(5) Strengthening the construction of compound foreign language teachers. The teacher is the source of education and teaching. To strengthen the construction of teachers is the most important foundation of the development of education, and to strive to create a noble morality and professional high-quality professional teachers is the key to improve the people's satisfaction with education. The prerequisite for training compound foreign language talents is to construct a compound foreign language teacher's team. At present, the level of professional knowledge of foreign language teachers in colleges and universities is not high, the knowledge structure is single, and there is a gap between the requirements for the cultivation of compound foreign language talents. The concrete construction scheme is: to improve the treatment of teachers, safeguard the 
interests of teachers, attract talented people to long-term and lifelong teaching; strengthen system innovation, improve the management system, and constantly improve the professional level of teachers; improve the training system, through training, academic exchanges and project funding and other ways to cultivate education backbone, "double type" teachers and academic leaders.

(6) Reform the traditional teaching methods and teaching means. The education methods should pay attention to students' feeling, questioning and logical reasoning, feelings and thinking process, variable infusion teaching as a heuristic teaching. Teaching should be timely guidance to students, inspire students' thinking and language expression, arouse students' positive thinking, encourage students to use their imagination and creativity, respect the views and questions raised by students, to make students master the creative thinking methods such as analogy, migration, reorganization, reverse and association, train students' flexibility, fluency and originality, and encourage students to learn independently. Teaching methods should play the advantages of information technology, make television, audio and video projectors, and computers and other modern media for teaching activities, and through text, images, video and audio to visual and auditory stimuli can improve the learning enthusiasm of students, deepen the understanding of knowledge, so as to improve the teaching efficiency and effect.

(7) Actively build a platform for school and enterprise cooperation. School enterprise cooperation is a mode of cooperation between schools and enterprises. It is a kind of "double win" mode, which pays attention to the quality of training, the focus on the study and practice of the enterprise, and the sharing of resources between schools and enterprises. Through cooperation, to promote to explore the curriculum reform scheme of college training objectives under the application of technology type, and promote textbook reform, improve the quality of academic achievement and feedback mechanism, promote the development of students to compound talents, make the university into a new state, to cultivate more talents for social needs. In the construction of school enterprise cooperation platform, enterprises can understand the school's students, teachers and teaching and so on, the school can understand the enterprise's project, personnel and equipment, as the use of resources. To solve the problem of information asymmetry in schools, teachers, students and enterprises, and provide a strong support for the realization of professional personnel training objectives.

\section{Conclusion}

Compound foreign language talents not only master the foreign language knowledge, but also master the relevant professional knowledge of economy, management, finance, law and information. This kind of talent has a very important role in promoting economic development and cooperation with foreign countries. The cultivation of compound foreign language talents are needed for social development, it is an important measure to solve the contradiction between the cultivation of foreign language talents with the needs of enterprise development, and it is also the objective requirement of "One Belt and One Road" national strategy. The strategies on training mode of compound foreign language talents on the background of "One Belt And One Road" solve the key problem of colleges and universities talents training at present. All colleges and universities in the implementation process, need to their own reality, change the concept of personnel training, focus on innovation and application ability, and service for the construction of "One Belt and One Road".

\section{References}

[1] W. X. Wang, "On the significance and measures of strengthening the training of foreign language talents under the guidance of 'the belt and road initiative'," Inner Mongolia Science Technology \& Economy, vol. 9, no. 14, pp. 35-36, 2015.

[2] Y. Li, C. F. Liu, W. Z. Lv, "Demand Analysis on Compound Foreign Language Talents on the Background of 'One Belt And One Road'," Journal of Higher Education, vol. 1, no. 11, pp. 22-23, 2015. 
[3] T. Y. Zhu, "Training on Compound Foreign Language Talents on the Background of 'One Belt And One Road': Taking Huzhou city as an example," Journal of Language and Literature Studies, vol. 36, no. 6, pp. 118-119, 2016.

[4] China education newspaper, "To strengthen the construction of teachers as the most important basic work," http://www.moe.edu.cn/publicfiles/bus/s5148/201309/157621.html, 2016-10-12.

[5] L. Q. Chen, L. Gao, "The role and relationship of training objectives and curriculum system in personnel training," Journal of Chifeng University (Natural Science Edition), vol. 30, no. 2, pp. 270-272 2014.

[6] J. H. Sun, "Education of students with two or more expertises and its promotion to economy," Journal of Henan Agricultural University, vol. 45, no. 4, pp. 493-496, 2011.

[7] X. Y. Xie, Q. X. Wu, "Reform and practice of foreign language practice teaching based on the cultivation of innovative talents," China University Teaching, vol. 34, no. 8, pp. 82-85, 2012.

[8] H. M. Zhang, "The Study of Innovation and Practice of College English on Students' Comprehensive and Applicative Ability based on College - enterprise Cooperation," Journal of Hubei Correspondence University, vol. 29, no. 7, pp. 135-136, 2016.

[9] Y. Tong, "On the training mode of compound Russian talents the situation of 'One Belt And One Road': A case study of Russian major in Shenyang Normal University," Chinese Russian Teaching, vol. 35, no. 3, pp. 88-92, 2016.

[10] Zhengfang' software, "Teaching management and service: school enterprise cooperation platform," http://www.zfsoft.com/type_jx/040000011008.html, 2016-10-2.

[11] Q. X. Liu, "Research on accelerating the cultivation of compound foreign language talents," Daqing Social Sciences, vol. 35, no. 4, pp. 138-140, 2016.

[12] Y. Q. Liu, "Research on training model of business English talents in Heilongjiang on the Background of 'One Belt And One Road'," Journal of Lanzhou Institute of Education, vol. 32, no. 6, pp. 135-136, 2016.

[13] J. Lu, "Research on the cultivation of compound foreign language talents on the strategy of 'One Belt And One Road'," Journal of Shaanxi University of Technology(Social Sciences), vol. 34, no. 2, pp. 101-104, 2016. 